\title{
STUDENT ATTITUDES TO THE TEACHING OF MATHEMATICS IN THE REPUBLIC OF SRPSKA
}

\author{
Dragica Milinković ${ }^{1}$, Sanja Opsenica ${ }^{2}$ \& Pero Spasojević ${ }^{3}$ \\ ${ }^{1}$ Assoc. Prof. Dr., University of East Sarajevo, Bosnia and Herzegovina, sadra@teol.net \\ ${ }^{2}$ Assoc. Prof. Dr., University of East Sarajevo, Bosnia and Herzegovina, \\ sanjalopsenica@gmail.com \\ ${ }^{3}$ Assoc. Prof. Dr., University of East Sarajevo, Bosnia and Herzegovina, spero@teol.net \\ ${ }^{*}$ Corresponding author
}

\begin{abstract}
The education system in the Republic of Srpska is mainly focused on the implementation of the curriculum and the adoption of content standardized by the program. Therefore, it is very often criticized and opposed because its orientation does not touch the "living context" of students and the expectations of an informal environment. This is especially true in the field of mathematical primary education since the mathematics that is taught in school is not the one that students are interested in, which requires reflection and applications in a real-life context, as it is taught in an abstract and highly formalized level, which requires logical reasoning. Hence, there is the antipathy and a high level of dissatisfaction and insecurity, especially during task solving which are the aim and the means of learning in math.

There is an unsatisfactory situation in the teaching of mathematics characterized by a multitude of negative evaluations and a large number of students who ask for "private lessons". This points us to re-examine all the parameters which have an impact on the results of mathematical education in primary schools, especially those that emphasize pupils who, according to the understanding of developmental psychology are in the center of the education system. To start with, it is urgent to point out the things which they are dissatisfied with in the teaching of mathematics and in a perspective that will adversely affect the development of mathematical literacy and mathematical competencies and then to their opinion, the teaching of mathematics in primary school could become more attractive and therefore more efficient.

Accordingly, the empirical part of the work is organized in order to examine students' attitudes about the state of primary mathematics teaching and the factors that can contribute to better and more efficient teaching. By using the scaling technique on a sample of 157 students from the 8th and 9th grades of primary schools in Bijeljina, we came to the results that indicate almost unanimous dissatisfaction of students with the teaching mathematics, first of all, with outdated mode. The study contributed to the opening of the most important problems in primary mathematics teaching, and indicated the paths to which the theory and practice of teaching methodology of mathematics education in primary education and education itself should be developed.
\end{abstract}

Keywords: mathematics, students' attitudes, the indicators of crisis, isolation from the real context. 


\section{INTRODUCTION}

Modern Primary School has long been marked by serious challenges due to the orientation that does not touch the "living context" of pupils and informal expectations of the environment because it is evident that if the school practice does not build on the children's acquired experience and if the knowledge is not associated with its implementation, results of learning will be short-lived (Vizek Vidović, Vlahović-Štetić, Rijavec \& Miljković, 2014). This is especially true in the increasingly present didactic and methodological materialism and formalism in teaching. The teaching-scientific disciplines that cause special interests of students are rare and in the field of mathematical primary education have retained the long perception of mathematics as a bogey-item, for which many students are destined to fail in school. The psychological experience of mathematics crashes desirable motivation in advance, it makes learning a "personal act" and not subject to any coercion. None of the learning program can be applied to different individuals universally, as a rule that raises the challenge of differentiated learning which encourages students to choose and participate in a program of personal satisfaction and with adequate interests. Therefore, a good curriculum should choose courses appropriate to the child's development and take into account the cognitive abilities of each developmental period.

Those problems are characterized by the education system in the Republic of Srpska, which is mainly focused on the implementation of the curriculum and the adoption of the standardized program content. It continues to emphasize "learning content" and "knowledge" (in today's terms of competence or literacy). According to the OECD (Office of Economic Cooperation and Development), mathematical literacy is the ability to recognize and understand the role of mathematics in the world, to make informed decisions and to apply mathematics in ways that meet the needs of an individual's life as a constructive, concerned and thoughtful citizen (OECD, 2010; OECD, 2014).This definition refers to the fact that mathematical literacy cannot be confined to the knowledge of mathematical terminology, facts and mathematical procedures, as well as the performance of certain operations although it involves having these competences. It involves active use and understanding of mathematics in everyday life because it emphasises relevant components of the concept of competence, knowledge, skills and abilities and therefore values and attitudes that students should acquire during their education which are important for further personal and professional development.

Bearing in mind that the central place in the teaching of mathematics belongs to the students and that their role in mathematics education at all levels is very important. Researchers in the seventies of the last century intensified engagement in the attitudes of students about math, their influence on success, motivation and learning strategies (Lester, Garofalo \& Kroll, 1989, pp. 75-88; Kloostermann, Raymond \& Emenaker, 1996, pp. 39-56). The results of numerous studies confirm a direct connection between the beliefs of students about math and success in learning mathematics (Mc Leod, 1992, pp. 575-596; Shoenfeld 1992, pp. 334370; Leder, Pehkonen \& Torner, 2002). The attitudes of students towards mathematics related to experiences during schooling, are evident even when they enroll in the Teacher Education (Kane, Sandretto \& Heath, 2002, 177-228).

When it comes to elementary school teaching in the Republic of Srpska, research results (Opsenica, Milinković \& Spasojević, 2016, pp. 210-221) confirm that students express a high level of dissatisfaction with the current situation. They would like change in teaching, different teachers and the social environment is seen as indifferent to the children-adolescents. School for decades, remains consistent to its "rigid" rules, ignoring the children of the modern era who are characterized by a strong rule of electronic media which, without a doubt, has a different impact on growing up. As possible causes of discontent amoungst students, researchers cite the conventional approach to teaching mathematics which does not give an adequate response to the demands of modern teaching methods (Milinković \& Pikula, 2011, pp. 100-111; Milinković, 2013, pp. 9-21) and as a possibility of overcoming, state the implementation of new methodologies and approaches to teaching, primarily related to the information technology and those which can interpret mathematics as a human activity and teaching process as an activity to solve everyday problems, namely the problem of context.

Research shows that the acquisition of mathematical knowledge, with regard to teaching and learning outside the context is very difficult as it can be uninteresting to pupils, while the knowledge acquired outside the broader context of thematic groups to which they belong, is difficult to generalize as they are not permanent or easily usable. However learning math in elementary school should not take place independently, isolated from the particular context of real life, without the influence of prior knowledge and experience of students, their beliefs, ways of thinking, understanding and so on. It is necessary that initial mathematical education is based on the principles of contextual teaching and learning.

Adequate teaching context that will enable the realization of set goals in primary mathematics teaching involves the application of methods, procedures, strategies and teaching approaches that include 
experiential learning in an authentic context. Preference is given to problem and situational oriented models of active and interactive mathematics teaching which, in interaction strategies for learning and teaching, students' characteristics and teaching context contributes directly to the achievement of learning outcomes and objectives of teaching. How teaching context has an important role in connecting mathematical concepts with meaning and significance of these facilities, it is necessary to adapt it to the students so they could engage in activities through a contextual approach to teaching, which direct outcomes of contextual learning and teaching.

Despite these desirable aspects of access to educational work, teaching mathematics in today's conditions in the Republic of Srpska is characterized by dissatisfaction and insecurity of students. They are usually accompanied by a sense of anxiety, especially during solving tasks which are the aim and means of learning in math. Between math anxiety and math achievement there is a statistically significant negative correlation because more anxious students make more mistakes, solve elementary math operations slower and had significantly lower scores in math (Cates \& Rhymer, 2003, pp. 23-34). Studies have shown that up to the eleventh year of the child's age their attitude towards mathematics is formed (Pavleković, 1997), which confirms that primary school mathematics anxiety directly causes the formation of aversion to mathematics in the future. People who express anxiety in connection with mathematics tend to avoid environments and professions in areas that require the use of mathematical skills (Ashcraft, 2002, pp. 181-185).

An unsatisfactory situation in the teaching of mathematics characterized by a multitude of negative evaluations and a large number of students who ask for "private lessons", points us to re-examine all the parameters which have an impact on the results of mathematical education in primary schools, especially those that emphasize pupils who, according to the understanding of developmental psychology, are in the center of the education system. Students put the personality of the teacher first and not the ability to teach mathematics which allows for errors found in problem solving to be treated as an opportunity for learning and not as an indication of ignorance, creating the way for the establishment of a working atmosphere that will be freed from fear and failure, but also helps students to better cope with their own assessment of the failure and ineffectiveness (Videnović \& Radišić, 2011, pp. 157-177). MacNab points out that teachers' understanding and application of modern conceptions of educational psychology, puts a child at the center of the educational system a basic condition for successful teaching and learning in mathematics (MacNab, 2000 , pp. 61-80). In addition, it is necessary to recognize the social status of mathematics, which indicates that the individual perception of mathematics can not be separated from the social framework in which it is created and been understood by the other (Brown, McNamara, Hanley \& Jones, 1999, pp. 299-322).

When starting school, children experience a change in their established pattern of behavior, a carefree period, which takes place under the shelter of the family and for them starts a whole new dimension of life. Psychologist Erik Erikson in his "Theory of psychosocial development" underlines the importance of the social environment for the development of the personality of each individual and from middle childhood, besides families, there are teachers appearing as new figures who represent the identification model. A schoolchilds task is to respond to the evolving requirements of the new academic environment. The successful completion of the tasks follows the experience of success and progress, a sense of competence, or rather a sense of inadequacy and inferiority if it fails to respond to the tasks (Erikson, 2008). The sense of psychological inferiority, as Adler says, may eventually lead to inferiority complex and to leave an indelible mark on the personality of a person and then the school, according to Bojanin, becomes a source of disease (Bojanin, 1990). The core of any good education is that the teacher asks their students to think and engage with them in encouraging dialogue, continuously checking progress and understanding believes Glasser (2010), which is precisely the subject of this paper. Do teachers encourage children? Do they follow their progress and understanding of the content and what it looks like from the perspective of students who are for the first time faced with certain content? On the other hand, mistakes made in this development phase only deepen the crisis which adolescent passes while establishing their own identity (Opsenica, 2013).

For a start it is necessary to point out all the things which students are dissatisfied with in teaching of mathematics and what perspective will adversely affect the development of mathematical literacy and mathematical competencies and then in their opinion, the teaching of mathematics in primary school could become more attractive, and thus more efficient.

\section{RESEARCH METHODOLOGY}

From a sample of 157 students, 105 girls and 52 boys in 8 th and $9^{\text {th }}$ grades from four primary schools in Bijeljina, the empirical research has been collected in order to ascertain the state of primary mathematics teaching from the perspective of students and to consider their suggestions for improving the results of work in this area. For this purpose, using the scaling technique, verification of students' opinions about indicators 
was carried out. Teaching of mathematics is based in primary school but on the other hand, primary school mathematics teaching is characterized as "outdated" and from their perspective should be modified to become a "favor" to students, to become mathematically literate and prepare them for everyday life. On this basis, the starting point was the hypothesis that students are dissatisfied with the current situation in the teaching of mathematics. To prove the hypothesis the authors have constructed an original instrument which scales 20 items. The instrument contains 2 subscales which determine the attitudes of students about:

(1) The situation of mathematics teaching in primary school

(2) Factors that could contribute to a better and more successful teaching of mathematics, which would be attractive to students and trained them to actively use and understand mathematics in everyday life.

The effectiveness of this instrument is determined by calculating Kronbachov Alfa coefficient $(\alpha=.768)$, which indicates the high reliability of the instrument.

Data obtained from the survey were processed using the statistical software package SPSS 24.0, while using descriptive statistics and analysis of variance (ANOVA).

\section{RESEARCH RESULTS AND DISCUSSION}

Empirical indicators from the first subscales (Table 1) indicate the operation and the situation in primary mathematics teaching. It is evident there is an extremely high percentage of agreement against statements relating to the implementation of teaching according the principle "teachers talk and the students listen" $(86.6 \%)$, lack of preparation of students for active use and understanding of mathematics in everyday life $(85.4 \%)$, lack of incentives for students to "work" more than a program that is standardized (82.2\%), aspects that teaching mathematics make it boring and seem obsolete (70.7\%). A high score in terms of stacking the students with the remaining six claims of the first subscales (from $58.6 \%$ to $68.2 \%$ ) indicates the obvious dissatisfaction of students with the present situation of the primary mathematics teaching because it is operated by outdated models of work. There is a primarily frontal method of teaching in which students are passive actors in the teaching process where they are required to reproduce knowledge and not criticallythink, which is necessary to develop while they are at the stage of formal operations, which in turn offers a multitude of possibilities for creative thinking. Researchers (Suzić, 2003) confirm that the success and affection of students by school subject depends on the personality of the teacher, their attitude towards the students, their competence in all aspects of the educational work in the school, their intelligence, creativity, versatility and awareness. In this case, aversion is created and it is given that students do not like math because of the teacher, their work methods and their attitudes towards them.

The answer to why these results are important is given by Huebner, Suldo, Smith \& McKnight (2004, pp. 8193), who say that an important component of students satisfaction with life is satisfaction with school. School satisfaction represents a construct that refers to the subjective assessment of satisfaction with various school aspects and the evaluation of how the student feels while at school and in this case, confirms that adolescents do not feel satisfied with the school. How important school satisfaction is for the general functioning of students is shown through research that students who express more satisfaction with school have a greater motivation to learn (Keys \& Fernandes, 1993). Recent studies however, show that the majority of adolescents are the least satisfied with school and show significantly greater satisfaction with other domains of life such as family, friends and environment (Huebner, Funk \& Gilman, 2000, pp. 53-64).

Table 1. Students' attitudes on the state of primary mathematics teaching

\begin{tabular}{|c|c|c|c|c|c|c|c|}
\hline \multirow[t]{2}{*}{ Attitudes } & \multicolumn{5}{|c|}{$\begin{array}{c}\text { Level } \\
(\%)\end{array}$} & \multicolumn{2}{|c|}{$\begin{array}{c}\text { Cumulative } \\
(\%) \\
\text { Level }\end{array}$} \\
\hline & 5 & 4 & 3 & 2 & 1 & 4 i 5 & 1 i 2 \\
\hline $\begin{array}{l}\text { Mathematics teaching is conducted in the } \\
\text { old way: teachers talk, students listen. }\end{array}$ & 67.5 & 19.1 & 7.6 & 3.8 & 1.9 & 86.6 & 5.7 \\
\hline $\begin{array}{l}\text { Teachers do not encourage students to } \\
\text { "work" more than standardized program. }\end{array}$ & 43.9 & 38.2 & 9.6 & 3.8 & 4.5 & 82.2 & 8.3 \\
\hline
\end{tabular}


IJAEDU- International E-Journal of Advances in Education, Vol. 3, Issue 7, April 2017

\begin{tabular}{|c|c|c|c|c|c|c|c|}
\hline $\begin{array}{c}\text { When evaluating, teachers "hunt" } \\
\text { ignorance, not what students are actually } \\
\text { learning. }\end{array}$ & 35.7 & 22.9 & 19.1 & 14.6 & 7.6 & 58.6 & 23.2 \\
\hline $\begin{array}{c}\text { In teaching the most important part is to } \\
\text { repeat what is taught in the classroom or } \\
\text { what is written in textbooks, making it dull } \\
\text { and outdated. }\end{array}$ & 47.1 & 23.6 & 11.5 & 8.9 & 8.9 & 70.7 & 17.8 \\
\hline $\begin{array}{c}\text { The interaction between students and } \\
\text { teachers is low. }\end{array}$ & 36.3 & 28.7 & 23.6 & 5.1 & 6.4 & 65.0 & 11.5 \\
\hline $\begin{array}{c}\text { Teachers expect the same from all students } \\
\text { despite different abilities and capabilities. }\end{array}$ & 38.9 & 29.3 & 19.1 & 8.3 & 4.5 & 68.2 & 12.8 \\
\hline $\begin{array}{c}\text { Teachers considered unnecessary and that } \\
\text { students suggest and opt for activities that } \\
\text { interest and motivate them. }\end{array}$ & 47.8 & 19.7 & 18.5 & 8.9 & 5.1 & 67.5 & 14.0 \\
\hline $\begin{array}{c}\text { Teaching mathematics does not prepare } \\
\text { students for active use and understanding } \\
\text { of mathematics in everyday life. }\end{array}$ & 68.8 & 16.6 & 8.9 & 5.1 & .6 & 85.4 & 5.7 \\
\hline $\begin{array}{c}\text { I do not like math because of the teacher, } \\
\text { their work methods and attitudes towards } \\
\text { students. }\end{array}$ & 42.7 & 18.5 & 21.0 & 12.1 & 5.7 & 61.1 & 17.8 \\
\hline $\begin{array}{c}\text { In most cases, school grades are unfair and } \\
\text { do not show what children know. }\end{array}$ & 37.6 & 21.0 & 15.9 & 16.6 & 8.9 & 58.6 & 25.5 \\
\hline
\end{tabular}

5 - I agree; 4 - I agree mostly; 3 - I am not sure; 2 - I do not agree mostly; 1 - I do not agree

In the analysis and discussion of the results of the other subscales on improving primary school teaching mathematics (Table 2), we noticed a higher average level of agreement in relation to the allegations from the previous subscales, with the exception of claims that students and teachers should be associates in the teaching process in which the greatest commitment is to "I'm not sure" $(38.9 \%)$. The results confirm that students have a clear idea of what would improve the teaching of mathematics in primary school and the best proof of which is to revitalize it and how it would be important. There is a stress on claims to "listen to the students' who focus on the need for a larger number of computers in teaching as on the Internet they can find a lot of interesting tasks $(91.1 \%)$, a belief that sometimes students have to propose how they will work on the next math lesson (84.7\%), the need for teachers to explain the math with examples from life $(84.1 \%)$, thinking that the students would prefer mathematics when all the students were "important" to the teacher and not just regarded as their "pet" (84.1\%), the necessity of applying new approaches and ways of working in order to have better motivation for learning mathematics $(79.0 \%)$. These results testify to the maturity of children and the need for their involvement in the educational process as a "participant" rather than "observers" and be aware that there is no "partnership" between teachers and students, just the relationship of trust that is essential in this sensitive development phase. In addition, it is obvious that the students have relevant information on modern strategies of teaching, democratization and vastly different school paradigms in schools around the world. Students are aware of the large individual differences among children which is not respected and how easy it is to observe the clearly privileged position of individuals. Also what and how should be changed so that teaching math in elementary school is closer to students needs and able to enrich them. In addition to these observations, it is necessary to mention the research of Karweit \& Slavin (1981, pp. 157-141), which stated that the time spent in the classroom, specifically in the subject of mathematics, is not fully utilized constructively and has large losses. According to the aforementioned authors, $11 \%$ of classes were not held because of a trip, lack of teachers, tests in other subjects or school events, $17 \%$ of the time is spent on delays, providing information and delivery of materials and $12 \%$ of the time children spend on sharpening pencils, daydreaming or having fun. Weinstein and Mignano's research reports that students in elementary school spend only a third of the time learning (Weinstein \& Mignano, 1993). 
IJAEDU- International E-Journal of Advances in Education, Vol. 3, Issue 7, April 2017

Table 2. Students' attitudes on improving primary school mathematics teaching

\begin{tabular}{|c|c|c|c|c|c|c|c|}
\hline \multirow[t]{2}{*}{ Attitudes } & \multicolumn{5}{|c|}{$\begin{array}{l}\text { Level } \\
(\%)\end{array}$} & \multicolumn{2}{|c|}{$\begin{array}{c}\text { Cumulative } \\
(\%) \\
\text { Level }\end{array}$} \\
\hline & 5 & 4 & 3 & 2 & 1 & 4 i 5 & $1 \mathrm{i} 2$ \\
\hline $\begin{array}{l}\text { Teachers should motivate us better to learn } \\
\text { mathematics by new ways of working. }\end{array}$ & 56.7 & 22.3 & 12.1 & 4.5 & 4.5 & 79.0 & 9.0 \\
\hline $\begin{array}{c}\text { Students and teachers need to be associates in } \\
\text { the teaching process. }\end{array}$ & 17.8 & 12.8 & 38.9 & 12.1 & 18.5 & 30.6 & 30.6 \\
\hline $\begin{array}{c}\text { The school should have more computers } \\
\text { because a lot of interesting tasks can be found } \\
\text { on the internet. }\end{array}$ & 75.8 & 15.3 & 2.5 & 4.5 & 1.9 & 91.1 & 6.4 \\
\hline $\begin{array}{c}\text { Mistakes made while solving the problems } \\
\text { should not always be treated as ignorance by } \\
\text { the teacher. }\end{array}$ & 55.4 & 21.7 & 13.4 & 6.4 & 3.2 & 77.1 & 9.6 \\
\hline $\begin{array}{l}\text { Teachers should explain mathematics using } \\
\text { examples from our life. }\end{array}$ & 72.6 & 11.5 & 5.7 & 5.7 & 4.5 & 84.1 & 10.2 \\
\hline $\begin{array}{l}\text { The most difficult problems should be solved at } \\
\text { school with teachers help, not at home. }\end{array}$ & 43.9 & 16.6 & 21.0 & 10.2 & 8.3 & 60.5 & 18.5 \\
\hline $\begin{array}{l}\text { More time in the lesson should be devoted to } \\
\text { content which interests us. }\end{array}$ & 51.0 & 21.7 & 21.7 & 2.5 & 3.2 & 72.6 & 5.7 \\
\hline $\begin{array}{l}\text { Sometimes students should propose what to do } \\
\text { in the next lesson. }\end{array}$ & 69.4 & 15.3 & 3.8 & 5.1 & 6.4 & 84.7 & 11.5 \\
\hline $\begin{array}{l}\text { I would enrich the lesson with a larger number } \\
\text { of interesting tasks. }\end{array}$ & 32.5 & 28.0 & 22.3 & 8.9 & 8.3 & 60.5 & 17.2 \\
\hline $\begin{array}{l}\text { I would prefer mathematics when all the } \\
\text { students were "important" to teacher and not } \\
\text { just their "pets" }\end{array}$ & 59.2 & 24.8 & 13.4 & .6 & 1.9 & 84.1 & 2.5 \\
\hline
\end{tabular}

5 - I agree; 4 - I agree mostly; 3 - I am not sure; 2 - I do not agree mostly; 1 - I do not agree

Many apparent discrepancies are based on gender in the analysis of attitudes towards subjects (Table 3 ). Statistically significant differences were found such as the assertion that girls express a greater degree of criticism towards teaching mathematics than boys: I would prefer Mathematics if all the students were "important" to the teacher not just their "pets" ( $F=8.986$ on the level of significance .003); Sometimes students should propose what to do in the next lesson ( $F=6.879$ on the level of significance .010); In most cases, school grades are unfair and do not show what children know ( $F=4.088$ on the level of significance .045). 
IJAEDU- International E-Journal of Advances in Education, Vol. 3, Issue 7, April 2017

Table 3. Differences in attitudes between girls and boys

\begin{tabular}{|c|c|c|c|c|c|}
\hline Attitudes & $\begin{array}{c}\text { Sum of } \\
\text { Squares }\end{array}$ & df & $\begin{array}{c}\text { Mean } \\
\text { Square }\end{array}$ & $\mathrm{F}$ & Sig. \\
\hline $\begin{array}{c}\text { I would prefer Mathematics if all the } \\
\text { students were "important" to the teacher not } \\
\text { just their "pets" }\end{array}$ & 6.647 & 1 & 6.647 & 8.986 & .003 \\
\hline $\begin{array}{c}\text { Students and teachers need to be } \\
\text { associates in the teaching process }\end{array}$ & 14.339 & 1 & 14.339 & 8.797 & .003 \\
\hline $\begin{array}{c}\text { Sometimes students should propose what } \\
\text { to do in the next lesson }\end{array}$ & 9.192 & 1 & 9.192 & 6.879 & .010 \\
\hline $\begin{array}{c}\text { In most cases, school grades are unfair and } \\
\text { do not show what children know }\end{array}$ & 7.479 & 1 & 7.479 & 4.088 & .045 \\
\hline
\end{tabular}

The exception is the dominant orientation of girls for the answer "I am not sure" when assessing attitude towards "Students and teachers need to be associates in the teaching process" ( $F=8.797$ on the level of significance .003) (Chart 1). At that claim girls opted in much greater number than boys for the answer "I do not agree". Although, because of the structure of the sample $(66.88 \%$ girls and $33.12 \%$ boys), we can take this with caution as it is quite obvious that girls are more suspect about relationship between students and teachers in the teaching of mathematics. This can be explained by the strong adolescent crisis that girls go through much earlier than boys, which puts into question any kind of authority as they are critical and aware of imperfection of teachers, as well as resistance to them.

Students and teachers need to be associates in the teaching process

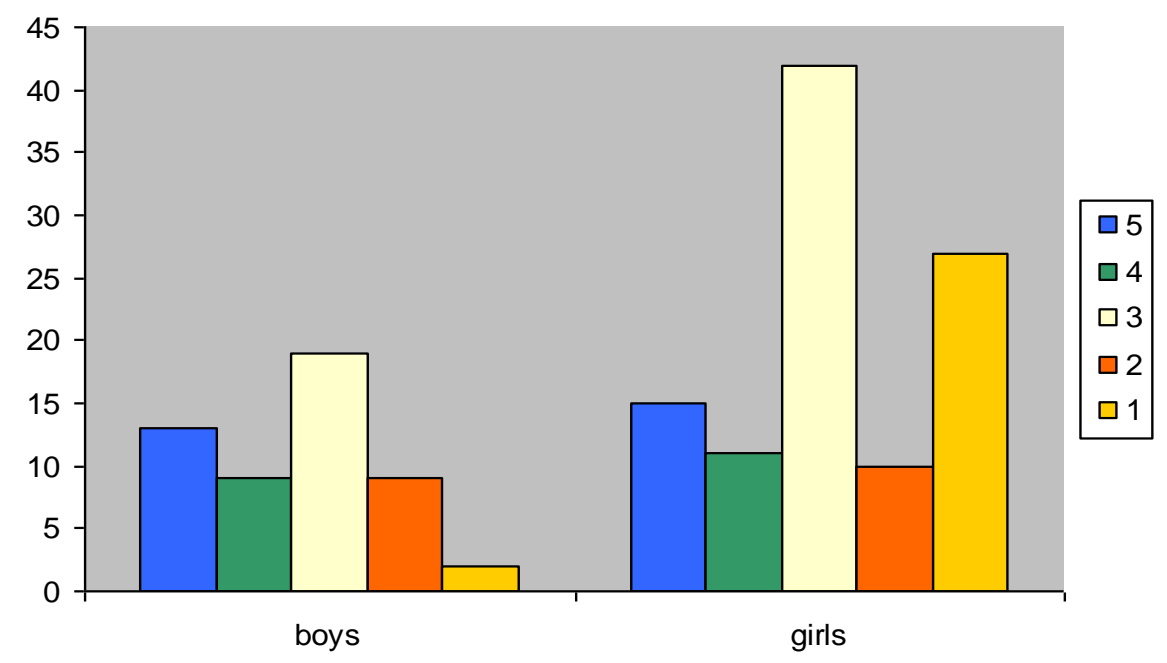

Chart 1: The attitudes of girls and boys towards the collaborative relationship of students and teachers

Summarizing the results of the research, we can conclude that the initial hypothesis is confirmed that students are dissatisfied with the present situation of the teaching of mathematics and also that they have concrete suggestions on how to make it more efficient and more attractive to other students.

These results are an indication that the primary school, despite a general social progress and opposed to other activities of society, remains loyal to the old paradigms used for several centuries. It is evident that we are still teaching students to just "sit and listen" while teachers talk and teach "their" way. It is very discouraging that they still rarely encourage students to independently work for themselves outside didactic curriculum and when evaluating, it is mainly hunting for what students "do not know" rather than defining 
what they objectively achieved while being taught and what life experience they gained ... (Tilman, 1994).

Instead of repeating what they "heard" in school or read in the textbooks, it is necessary to apply the knowledge in a real context in order to create independent and inventive people. Is it pertinent to ask why the teachers and students in schools are mostly in "two worlds" and that, as a rule, they are two opposing and irreconcilable worlds? It is indisputablly important to explain the fact that teachers still require the "same" and "equal" from all students and why teachers are hardly convinced that school is 'preparation for life' and that only knowledge is not enough (Pešikan, 2010, pp. 157-184). When it comes to these issues, students have very serious remarks and observations that school and society must not turn a deaf ear to.

\section{CONCLUSION}

The study contributed to highlighting some of the most important problems in primary mathematics teaching and indicated the correct paths in which the theory and practice of teaching methodology of mathematics education in primary education and education should be developed. The most important result of the research is almost unanimous dissatisfaction from the students with teaching practices in mathematics. In particular, the outdated mode of work and high expectations of "didactic and methodological materialism and formalism," which represent our pedagogical heritage. It is evident that the teaching of mathematics in primary school is focusing on criticizing and challenging rather than showing affection for students and assessing their development needs. Misunderstanding individual differences, the distance at which the teachers are in relationship to them, instead of support as adequate orientation of the school, students understood as a deficiency of the school environment, That proves that the school does not believe in the power of students to be agents of their own development, and that the early independence and involvement of students is fruitful for their growth. With this in mind, special attention should be paid to the improvement of teaching primary school mathematics by introducing new ways of working, new approaches and strategies of teaching and learning, enriching the work in a lesson with a larger number of interesting tasks and devoting more time to content that students are interested in to get better motivation for learning mathematics. Students particularly emphasize the need for a larger number of computerized classrooms and the desire that mathematic is occasionally prepared and implemented in a way that they suggest. It is especially important to point out that a large number of students do not like math because of the teacher and their relationship to their students, only respecting the views of their "pets" while other students are deemed less important.

In more far-reaching terms, the importance of this research can be seen from the perspective of preparing teaching staff of the future, especially in the field of methodical training for systematic mathematical education of children of primary school age, given the "defects" of today's mathematics teaching and the measures proposed by the students for their elimination.

The results of this study suggest that a positive evaluation of the school by the student plays an important role not only in academic achievement, but also to develop inner motivation and ultimately, the overall mental health of students. These results support the understanding of the authors who believe that the successful development of young people is necessary to create conditions that will encourage the building of overall strength and the positive personality characteristics of a person and thus prevent maladaptive behaviour patterns (Seligman, 2002, pp. 3-9). In adolescence, a period of highly turbulent changes in all aspects of development, the school holds key emotional context and is crucial for the development of a persons' personality. Therefore, it is obvious that the school satisfaction is a factor that greatly affects the general welfare of students.

We hope that this study will encourage other researchers to investigate this problem but also help teachers to foster a collaborative relationship with the students to respect their opinion regarding the organization and selection of lesson content and that they adequately motivate students to learn mathematics in the schooling process.

\section{REFERENCE LIST}

Ashcraft, M. A. (2002). Math anxiety: Personal, educational, and cognitive co nsequences. Current Directions in Psychological Science, 11 (5). 
Bojanin, S. (1990). Škola kao bolest. Beograd: Biblioteka XX vek.

Brown, T., McNamara, O., Hanley, U. \& Jones, L. (1999). Primary Student Teachers' Understanding of Mathematics and its Teaching. British Educational Research Journal, 25 (3).

Cates, G. L. \& Rhymer, K. N. (2003). Examining the relationship between mathematics anxiety and mathematics performance: An instructional hierarchy perspective. Journal of Behavioral Education, 12 (1).

Erikson, E.H. (2008). Identitet i životni ciklus. Beograd: Zavod za udžbenike.

Glasser, W.M.D. (2010). Quality school teacher. New York: HarperCollins Publisher.

Huebner, E.S., Funk, B.A. \& Gilman, R. (2000). Cross-sectional and longitudinal psychosocial correlates of adolescent life satisfaction reports. Canadian Journal of SchoolPsychology, 16.

Huebner, E.S., Suldo, S.M., Smith, L. C. \& McKnight, C. G. (2004). Life Satisfaction in children and youth: Empirical foundations and implications for school psychologists. Psychology in the Schools, 41(1).

Kane, R., Sandretto, S. \& Heath, C. (2002). Telling half the story: A critical review of research on the teaching beliefs of university academics. Review of Educational Research, 72 (2).

Karweit, N.L. \& Slavin, R.E. (1981). Measurement and modeling choices in studies of time and learning. American Educational Reasearch Journal, 18.

Kloosterman, P., Raymond, A. M. \& Emenaker, C. (1996). Students' Beliefs about Mathematics: A ThreeYear Study. The Elementary School Journal, vol. 97.

Leder, G. C., Pehkonen, E. \& Törner, G. (Eds.) (2002). Beliefs: A hidden variable in mathematics education?. Dordrecht: Kluwer Academic Publishers.

Lester, F. K., Garofalo, J. \& Kroll, D. L. (1989). Self-Confidence, Interest, Beliefs, and Metacognition: Key Influences on Problem-Solving Behavior. In D. B. McLeod \& V. M. Adams (Eds.), Affect and Mathematical Problem Solving. New York: Springer-Verlag.

MacNab, D. (2000). Raising Standard in Mathematics Education: Values, Vision and TIMSS. Educational Studies in Mathematics, 42 (1).

McLeod, D. B. (1992). Research on affect in mathematics education: A reconceptualization. In D.A. Grouws (Eds.), Handbook of Research on mathematics teaching and learning, New York: Macmillan.

Milinković, D. \& Pikula, M. (2011). Obrazovni softver kao perspektiva učenja putem rješavanja problema, Nova škola, VI (8).

Milinković, D. (2013). Metoda fokusnog dijagrama u funkciji razvijanja logičkog mišljenja i rasuđivanja, Norma, XVIII (1).

Opsenica, S. (2013). Porodica i ciljne orijentacije mladih. Banja Luka: Grafid.

Opsenica, S., Milinković, D. \& Spasojević, P. (2016). Obilježja osnovne škole iz perspektive učenika. U Jukić, K. Bogatić, S. Gazibara, S. Pejaković, S. Simel, A. Nagy Varga, V. Campbell-Barr (Eds..), Conference Proceedings Book (academic papers), International Scientific Conference 'Global and Local Perspectives of Pedagogy', Osijek: Filozofski fakultet, Sveučilište Josipa Jurja Strossmayera.

Pavleković, M. (1997). Metodika nastave matematike s informatikom I. Zagreb: Element.

Pešikan, A. (2010). Savremeni pogled na prirodu školskog učenja i nastave: sociokonstruktivističko gledište i njegove praktične implikacije. Psihološka istraživanja, XIII (2).

Schoenfeld, A. (1992). Learning to think mathematically: problem solving, metacognition and sense making in mathematics. In D.A. Grows (Eds.), Handbook of research on mathematics learning and teaching, New York: Macmillan.

Seligman, M.E.P. (2002). Positive psychology, positive prevention, and positive therapy. In C. R. Snyder \& S.J. Lopez (Eds.), Handbook of Positive Psychology. New York: Oxford University Press.

Suzić, N. (2003). Osobine nastavnika i odnos učenika prema nastavi. Banja Luka: Teacher Training Centre.

Tillmann, K. J. (1994). Teorije škole. Zagreb: EDUCA.

Videnović, M. \& Radišić, J. (2011). Anksioznost u vezi sa učenjem matematike: Matematika - bauk ili ne? Psihološka istraživanja, XIV (2). 
Vizek Vidović, V., Vlahović-Štetić, V., Rijavec, M. \& Miljković, D. (2014). Psihologija obrazovanja, Zagreb: IEP-Vern.

Weinstein, C. \& Mignano, A. Jr. (1993). Elementary classroom menagement: Lesson from research and practice. New York: McGraw-Hill. 